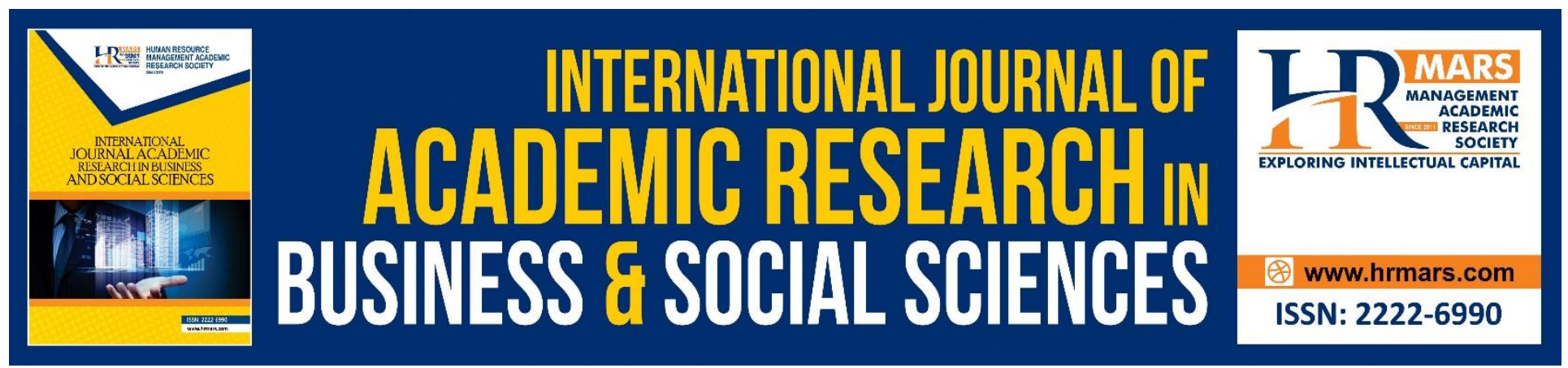

\title{
Implementation of Directive 2005/29/EC Concerning Unfair Business-to-Consumer Commercial Practices in the Internal Market
}

Ilie-Cătălin Ungureanu

To Link this Article: http://dx.doi.org/10.6007/IJARBSS/v8-i7/4393

DOI: $\quad 10.6007 /$ IJARBSS/v8-i7/4393

Received: 25 May 2018, Revised: 11 June 2018, Accepted: 29 June 2018

Published Online: 08 July 2018

In-Text Citation: (Ungureanu, 2018)

To Cite this Article: Ungureanu, I.-C. (2018). Implementation of Directive 2005/29/EC Concerning Unfair Business-to-Consumer Commercial Practices in the Internal Market. International Journal of Academic Research in Business and Social Sciences, 8(7), 512-519.

Copyright: (c) 2018 The Author(s)

Published by Human Resource Management Academic Research Society (www.hrmars.com)

This article is published under the Creative Commons Attribution (CC BY 4.0) license. Anyone may reproduce, distribute, translate and create derivative works of this article (for both commercial and non-commercial purposes), subject to full attribution to the original publication and authors. The full terms of this license may be seen

at: http://creativecommons.org/licences/by/4.0/legalcode

Vol. 8, No. 7, July 2018, Pg. 512 - 519

http://hrmars.com/index.php/pages/detail/IJARBSS

JOURNAL HOMEPAGE

Full Terms \& Conditions of access and use can be found at http://hrmars.com/index.php/pages/detail/publication-ethics 


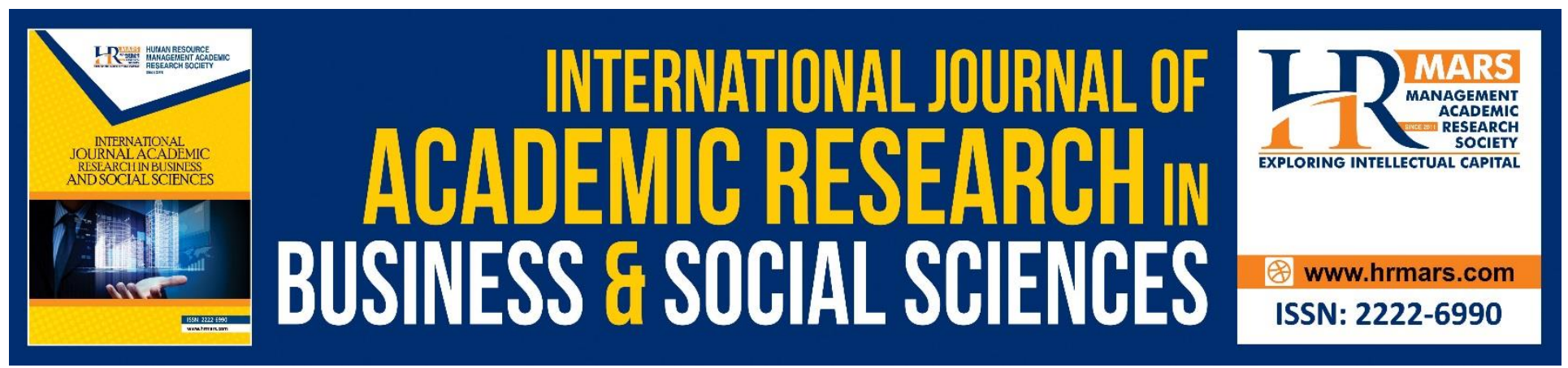

\title{
Implementation of Directive 2005/29/EC Concerning Unfair Business-to-Consumer Commercial Practices in the Internal Market
}

\author{
Ilie-Cătălin Ungureanu \\ Juridical Researches Institute, Romanian Academy, Romania \\ Email: avocatcatalinungureanu@yahoo.com
}

\begin{abstract}
Directive 2005/29/EC aimed at approximating the laws of the Member States on unfair commercial practices, including unfair advertising, which directly harm consumers' economic interests. Romania's accession to the European Union on January 1, 2007 imposed the necessity to implement this directive in the national law. If implementation in the other EU countries has raised a number of difficulties in correlating internal regulations, in the case of Romania, a country where market economy mechanisms were still in progress, the implementation was achieved directly by taking over ad litteram the majority of the provisions contained in the Community regulation. We have shown in the present study that this is a constant practice of the Romanian legislator and we have tried to identify the advantages and disadvantages of this law making process. Moreover, even this servile takeover of the text of the Directive into the domestic law was not without inaccuracies, which were corrected by subsequent regulations. We have also tried to identify the novelty elements brought by the national legislator as well as the manner in which this regulation fits into the Romanian consumer protection system.
\end{abstract}

Keywords: Unfair commercial practices, traders, consumers, misleading practices, aggressive practices, average consumer

Implementation of Directive 2005/29/EC

In 2005 the European Union Directive on Unfair Commercial Practices was adopted ${ }^{1}$. This regulation had as its starting point the regulations contained in the Directive concerning comparative

\footnotetext{
${ }^{1}$ Directive 2005/29/EC of the European Parliament and of the Council of 11 May 2005 concerning unfair business-toconsumer commercial practices on the internal market and amending Council Directive 84/450/EEC, Directives 97/7/EC, 98/27/EC and 2002/65/EC of the European Parliament and of the Council and Regulation (EC) No. 2006/2004 of the European Parliament and of the Council, OJ 2005 L 149/22.
} 
INTERNATIONAL JOURNAL OF ACADEMIC RESEARCH IN BUSINESS AND SOCIAL SCIENCES Vol. 8, No. 7, July 2018, E-ISSN: 2222-6990 @ 2018 HRMARS

and misleading advertising ${ }^{2}$, and as its stated purpose the removal of unfair commercial practices materialized in distorting consumer economic behaviour with regard to commercial decisions ${ }^{3}$.

As a result of Romania's accession to the European Union on January 1, 2007, the correlative obligation to implement EU directives in the national legislation has also intervened. Directive 2005/29/EC was implemented in the national law by Law no. 363 of 21 December 2007 on fighting unfair business-to-consumer commercial practices and harmonizing the regulations with the European consumer protection legislation ${ }^{4}$. This regulation has undergone several amendments over time. Thus, the Law no. 363/2007 was first amended by Law no. 130 of 30 June 2010 amending Article 15 para. (1) and (2) of Law no. 363/2007. Other changes were also brought by Law no. 33 of 9 March 2015 for the amendment of the Law no. 363/2007 and Law no. 51 of 30 March 2016 concerning the approval of the Government Ordinance no. 37/2015 for the amendment of certain regulatory deeds in the field of consumer protection.

This study aims to identify some difficulties in the implementation of Directive 2005/29/EC in the national laws of the Member States and whether these difficulties have been overcome by the Romanian legislator.

As it is known, the Directive contains general provisions on "misleading practices" (which are classified as "misleading actions" and "misleading omissions") and "aggressive practices"; also as a general regulation, the directive refers to practices used for attracting customers that "are contrary to the requirements of professional diligence" 5 . It seems that the regulation concerning "professional diligence" tends to include also the special regulations on misleading practices and aggressive practices (Howells et al., 2006). There is also a list of 31 practices which, in any circumstance, can be considered unfair, irrespective of the application of the general regulation on misleading practices and aggressive practices ${ }^{6}$.

The Directive requires Member States to ensure adequate and effective measures to fight unfair practices; these measures also include the means by which individuals and organizations subject to national regulation and justifying a legitimate interest in fighting unfair commercial practices can rely on legal or administrative action against such practices ${ }^{7}$.

As a general observation, it is necessary to point out that the implementation of Directive 2005/29/EC in the Romanian legislation did not raise any issues related to the correlation of preexisting legal norms. At the time of accession, Romania had legislation on consumer protection ${ }^{8}$, but it contained a general regulation and the means of protection were insufficient. Therefore, the implementation of the Directive was carried out on an empty regulatory space and under these conditions the Romanian legislator was able to transpose the Directive into law by almost taking over its entire text.

\footnotetext{
${ }^{2}$ Directive 84/450/EEC of the Council of 10 September 1984 concerning misleading and comparative advertising. This was subsequently repealed by DIRECTIVE 2006/114/EC of the European Parliament and of the Council of 12 December 2006 concerning misleading and comparative advertising, OJ L 376, 27.12.2006.

${ }^{3}$ In accordance with Article 2 letter k) of the Directive "transactional decision" means any decision taken by a consumer concerning whether, how and on what terms to purchase, make payment in whole or in part for, retain or dispose of a product or to exercise a contractual right in relation to the product, whether the consumer decides to act or to refrain from acting;

${ }^{4}$ Law no. 363 of 21 December 2007 was published in the Official Gazette of Romania, Part I no. 899 of 28/12/2007

${ }^{5}$ Articles 5-9.

${ }^{6}$ Annex 1 of the Directive.

${ }^{7}$ Article 11 of the Directive.

${ }^{8}$ Ordinance no. $21 / 1992$ on consumer protection.
} 
INTERNATIONAL JOURNAL OF ACADEMIC RESEARCH IN BUSINESS AND SOCIAL SCIENCES Vol. 8, No. 7, July 2018, E-ISSN: 2222-6990 @ 2018 HRMARS

In this respect, under Article 2 of the Law no. 363 of 21 December 2007 there are defined the terms by which this regulation operates. As an example, let us mention, for instance, the definition of the consumer. This is "any natural person or group of natural persons constituted in associations which, in commercial practices covered by this law, is acting for purposes that are outside their trade, business, production, craft or profession" 9 . The definition of the consumer given by the Directive is "any natural person who, in commercial practices covered by this Directive, is acting for purposes which are outside his trade, business, craft or profession"10. As it can be noticed, apart from the fact that the definition in Romanian law extends its scope to associations formed by natural persons, the definition of the consumer is almost identical in the two regulations.

However, the Romanian law also contains the definition of the average consumer. This notion was a controversial issue in the process of adopting the Directive. The original proposal for the Directive contained a definition of the average consumer as "the consumer who is reasonably well informed and reasonably observant and circumspect" (Howells et al., 2006). Finally, this definition was dropped and they only kept the reference to the case-law of the European Court of Justice in the preamble to the Directive (paragraph 18). This point was extended in the final version of the Directive so as to include passages from the CJEU case-law, clearly specifying what the average consumer is "this Directive takes as a benchmark the average consumer, who is reasonably well-informed and reasonably observant and circumspect, taking into account social, cultural and linguistic factors, as interpreted by the Court of Justice". The reason for not including a clear definition of the average consumer in the Directive was based on the possibility of developing this notion by jurisprudence.

However, the Romanian legislator preferred to include in the Law no. 363 of 21 December 2007 the definition of the average consumer as shown in the preamble to the Directive. Thus, Article $2 \mathrm{~m}$ ) of the Law stipulates that "the average consumer is the consumer considered to be reasonably informed, observant and circumspect, taking into account social, cultural and linguistic factors". It is noted that this definition is also susceptible to legal development, the reasonableness being judged on a case-by-case basis by the court of law or the administrative authority.

In the initial version of Law no. 363 of 21 December 2007 the definition of distortion of the consumer's behaviour has been poorly implemented. According to Article 2 e) of the Directive "to materially distort the economic behaviour of consumers" means using a commercial practice to appreciably impair the consumer's ability to make an informed decision, thereby causing the consumer to take a transactional decision that he would not have taken otherwise. In this respect, it is noted that the trader's unfair practice is used to impair the buyer's behaviour. The Romanian legislator transposed this definition by providing that "the substantial distortion of the economic behaviour of consumers means using a commercial practice that significantly impairs the consumers' ability to make an informed decision, decision that they would not have taken otherwise" (Article 2 letter e of the Law). As we can see, the transposition unjustifiably broadened the notion of distortion of consumer behaviour, including also certain practices that were not consciously and deliberately used by the trader to influence his decision. This faulty transposition was remedied by Law No. 33 of 9 March 2015, which included the requirement that unfair practices should be used to influence the consumer's decision ${ }^{11}$.

\footnotetext{
${ }^{9}$ Article 2 letter a) of Law no. 363 of 21 December 2007.

${ }^{10}$ Article 2 letter a) of the Directive.

${ }^{11}$ The substantial distortion of the economic behaviour of consumers - using a commercial practice to considerably impair the consumers' ability to make an informed decision, thereby causing them to take a decision that they would not have taken otherwise (Article 2 letter e) of the Law no. 363 of December 21, 2007 updated by the Law no. 33 of 9 March 2015).
} 
INTERNATIONAL JOURNAL OF ACADEMIC RESEARCH IN BUSINESS AND SOCIAL SCIENCES Vol. 8, No. 7, July 2018, E-ISSN: 2222-6990 @ 2018 HRMARS

As far as the scope of the law is concerned, it has been largely defined according to the provisions of the Directive. However, the Romanian legislator provided in addition to the Community norm that "this law is without prejudice .... to the provisions on financial services, as defined in Government Ordinance no. 85/2004 on the protection of consumers upon the conclusion and implementation of distance contracts for financial services, as approved by Law no. 399/2004, or to the provisions relating to immovable property, where such provisions are more restrictive or more rigorous than those in this Law". It was therefore expressly stipulated that the law did not modify the provisions of Government Ordinance no. 85/2004 on the protection of consumers upon the conclusion and implementation of distance contracts for financial services, a distinct protection regulation.

As regards the scope of the Directive, a remark on intellectual property rights is also required. In the Preamble, among other examples listed in Article 3, it is expressly stated that the Directive is without prejudice to the rules on intellectual property in force at Community and national level. These rights are no longer listed in Article 3 of the Directive, which defines its scope. The reason for this omission cannot be justified. In most Member States, there have been reported some forms of infringement of intellectual property rules to the detriment of competitors, such as servile imitation, which are at the edge of unfair practices (Schulze and Schulte-Nölke, 2003). Therefore, the unfair use of intellectual property rights to the detriment of consumers is likely to affect the field covered by the Directive as well. It can be said that it is unlikely that the editors of the Directive intended to restrict its scope in this area. This is confirmed by the final version of the Directive. In Annex 1 on commercial practices which are unfair in all circumstances, there has been added an explicit provision regarding the imitation meant to cause confusion on the consumer.

Also, some intellectual property rights such as trademarks or protected names may be used to mislead consumers. If a trader acts in such a way, the reference to these rights only in the Preamble to the Directive should not exclude the applicability in this case. We note that the Romanian legislator did not take over the applicability of the law in the field of intellectual property rights from the Preamble either, as it did in the case of the average consumer definition.

Another provision that has been wrongly transposed into Romanian law refers to the conditions of incorrect commercial practices. Article 5 paragraph (2) of the Directive states that " $A$ commercial practice shall be unfair if: (a) it is contrary to the requirements of professional diligence, and (b) it materially distorts or is likely to materially distort the economic behaviour with regard to the product of the average consumer whom it reaches or to whom it is addressed, or of the average member of the group when a commercial practice is directed to a particular group of consumers". Consequently, the conditions set out under points (a) and (b) are cumulative. The Romanian legislator transposed this regulation into Article 4 paragraph (1) of the law, which in its initial form stipulated: "A commercial practice is incorrect if: a) it is contrary to the requirements of professional diligence; $b$ ) it fundamentally distorts or is likely to fundamentally distort the economic behaviour of the average consumer whom it reaches or to whom it is addressed, or of the average member of a group when a commercial practice is addressed to a particular group of consumers". As it can be noticed, the transposition was flawed because, by way of interpretation, a commercial practice could be considered to be incorrect if it fulfilled either condition (a) or condition (b). By Government Ordinance no. 37 of 26 August 2015 the regulation was amended and the current form of the article quoted is "A commercial practice is incorrect if the following conditions are cumulatively met: a) it is contrary to the requirements of professional diligence; $b$ ) it fundamentally distorts or is likely to fundamentally distort the economic behaviour of the average consumer whom it reaches or to whom it is addressed, 
INTERNATIONAL JOURNAL OF ACADEMIC RESEARCH IN BUSINESS AND SOCIAL SCIENCES Vol. 8, No. 7, July 2018, E-ISSN: 2222-6990 @ 2018 HRMARS

or of the average member of a group when a commercial practice is addressed to a particular group of consumers".

Thus, the legislator returned to the letter and spirit of the regulation contained in Directive 2005/29/EC, by explicitly specifying the need to meet the cumulative conditions under (a) and (b).

As regards the definition of unfair practices, misleading actions and misleading omissions, as well as their conditions of existence, these have been taken over in the Romanian legislation, without any changes, from the text of the Directive.

There are particulars with regard to the implementation of the protection mechanisms covered by the Directive. Article 11 provides that "Member States shall ensure that adequate and effective means of combating unfair commercial practices are put in place to enforce compliance with the provisions of this Directive in the interests of consumers. Such means shall include legal provisions under which persons or organisations regarded under national law as having a legitimate interest in combating unfair commercial practices, including competitors, may: (a) take legal action against such unfair commercial practices

and/or (b) bring such unfair commercial practices before an administrative authority competent either to decide on complaints or to initiate appropriate legal proceedings". As noted, the Directive left at the discretion of the Member States the regulation of protection instruments, and they could opt for the establishment of judicial or administrative means.

The Romanian legislator stipulated maximum protection in this respect. It has made it possible for persons with a legitimate interest in combating abusive practices to appeal either to an administrative procedure or to a direct legal proceeding. Article 10 (1) of the Law no. 363 of 21 December 2007 states that "In order to stop and fight unfair commercial practices, persons or organizations that, according to the law, have a legitimate interest may either notify the National Consumer Protection Authority ${ }^{12}$ of incorrect commercial practices in order that the latter could decide on complaints, or bring legal proceedings against traders who have committed, or are likely to commit, unfair commercial practices". Consequently, interested parties can choose the administrative path by notifying the National Authority for Consumer Protection (ANPC), or can appeal directly to the court by notifying the competent court. The option so expressed is relevant in terms of the means of protection and the penalties applied. The National Authority for Consumer Protection may order the following measures:

- termination or initiation of appropriate legal proceedings to end unfair business practices;

- banning or setting up appropriate legal proceedings to end unfair business practices, even if they have not yet been put into practice, but this is imminent;

- communication by the National Audiovisual Council, within 5 business days of receipt of the request, of data identifying the natural or legal persons involved in the realization of audiovisual

\footnotetext{
12 The National Authority for Consumer Protection was established on the basis of Government Emergency Ordinance no. 2/2001 for the establishment, organization/reorganization or functioning, as the case may be, of ministries, specialized bodies of central public administration and public institutions, and of Government Decision no. 700/2012 on the organization and functioning of the National Authority for Consumer Protection, as subsequently amended and supplemented. The National Authority for Consumer Protection operates as a specialized body of the central public administration, having its own legal form, and is subordinated to the Government and coordinated by the Minister of Economy, financed entirely from the state budget through the budget of the Ministry of Economy. The Authority coordinates and implements the Government's strategy and policy in the field of consumer protection, acts to prevent and combat practices that harm the lives, health, security and economic interests of consumers. The Authority streamlines state activity in the field of direct and indirect consumer protection through market research, consumer information and education and strengthening the decision-making capacity.
} 
INTERNATIONAL JOURNAL OF ACADEMIC RESEARCH IN BUSINESS AND SOCIAL SCIENCES

Vol. 8, No. 7, July 2018, E-ISSN: 2222-6990 @ 2018 HRMARS

advertising considered to be an unfair commercial practice as well as a copy of the broadcast advertising material.

As far as the penalties are concerned, Article 13 of the Directive states that "Member States shall lay down penalties for infringements of national provisions adopted in application of this Directive and shall take all necessary measures to ensure that these are enforced. These penalties must be effective, proportionate and dissuasive". As noted, the European legislator has left a wide margin of discretion to the Member States as to the nature of the penalties in the field. The only requirement is that they be effective, proportionate and dissuasive. This circumstance has led to discussion in the specialty literature on the criteria for assessing the proportionality of penalties (Howells et al., 2006). The Romanian legislator opted for the establishment of contravention liability in the field. Article 15 of Law no. 363/2007 provides for contravention sanctions as follows:

- fine between RON 2,000 and RON 10,000 for the use of unfair commercial practices;

- fine between RON 5,000 and RON 1,000,000 for the use of misleading commercial practices;

- fine between RON 2,000 and RON 100,000 for the use of aggressive commercial practices.

However, in the process of applying Law No. 363 it was noted that the establishment of general limits for the fine, without other criteria of appreciation, is not sufficient. In order to give relevance to the principle of proportionality, Law no. 51 of 30 March $2016^{13}$ introduced Article 16, which makes the amount of the fine conditional on the concrete economic situation of the culpable trader. Thus, for the use of unfair commercial practices and abusive commercial practices, the penalties provided for in Article 15 shall apply as follows:

- between RON 2,000 and RON 10,000, for traders with up to 9 employees and achieving a net annual turnover of up to EUR 2 million, equivalent in RON;

- between RON 3,000 and RON 50,000, for traders with 10 to 49 employees, and achieving a net annual turnover of up to EUR 50 million, equivalent in RON;

- between RON 5,000 and RON 100,000, for traders with over 50 employees and achieving a net annual turnover of more than EUR 50 million, equivalent in RON.

Similarly, for the use of misleading commercial practices, the penalties provided for in Article 15 shall apply as follows:

- between RON 5,000 and RON 15,000, for traders with up to 9 employees and achieving a net annual turnover of up to EUR 2 million, equivalent in RON;

- between RON 6,000 and RON 50,000, for traders with 10 to 49 employees, and achieving a net annual turnover of up to EUR 50 million, equivalent in RON;

- between RON 7,000 and RON 100,000, for traders with over 50 employees and achieving a net annual turnover of more than EUR 50 million, equivalent in RON.

The only problem related to the implementation of penalties in the national legislation is the issue of the dissuasive effect of these penalties. In fact, it should be discussed whether a sanction of up to RON 100,000 (approximately EUR 21,593) would have a dissuasive effect on a trader with a net turnover of more than EUR 50 million annually. However, it should be noted that contravention liability does not remove the civil liability that can be engaged under the conditions of the common law, the use of unfair commercial practices being at the same time a civil offence.

\footnotetext{
${ }^{13}$ Published in the Offical Gazette no. 257 of 6 April 2016.
} 
INTERNATIONAL JOURNAL OF ACADEMIC RESEARCH IN BUSINESS AND SOCIAL SCIENCES

Vol. 8, No. 7, July 2018, E-ISSN: 2222-6990 @ 2018 HRMARS

\section{Conclusions}

In conclusion, in relation to those analysed in the present study we believe that the implementation of Directive 2005/29/EC in the national law has largely achieved the objectives imposed by the Community legislator and provided consumers with the tools to protect them against unfair commercial practices. One criticism that could be brought about by the way in which the Directive has been implemented is the taking over of its text ad litteram. However, this manner of implementation leaves the option of a jurisprudential development and the possibility of rigorous analysis and application of the principles adopted by the European Court of Justice.

\section{References}

Howells G.G., Micklitz H., Wilhelmsson T. (2006). European Fair Trading Law, The Unfair Commercial Practices Directive, Ashgate Book, pp. 2 - 276.

Schulze R., Schulte-Nölke H. (2003). Analysis of National Fairness Laws Aimed at Protecting Consumers in Relation to Commercial Practices (June 2003)

http://europa.eu.int/comm/consumers/cons_int/safe_shop/fair_bus_pract/green_pap_comm/stud ies/unfair_practices_en.pdf. 